\title{
Medyatik Şiddetin Eleştirisine Sinemasal Bir Yaklaşım: Katil Doğanlar
}

\author{
Hakan Sağlam (Dr.) \\ mydreams_04@hotmail.com \\ Orcid: 0000-0003-0433-6620
}

Başvuru Tarihi: 27.06.2018

Yayına Kabul Tarihi: 18.12.2018

Yayınlanma Tarihi: 21.01.2019

\section{Öz}

Çağımızın baş döndürücü teknolojik gelişiminin çok sayıda sosyal problemi de beraberinde getirdiği ve bu problemlerin çözülmek bir yana her geçen gün büyümeye devam ettiği hemen tüm sosyal bilimcilerin ortak kanıya vardığı hususların bașında gelmektedir. Kökleri insanlı tarihinin en derin noktalarına kadar inen şiddet, toplumsal gündemdeki yerini her daim muhafaza etmektedir. Sosyal medyanın ortaya çıkıp hızla yaygınlaşmasıyla medyanın toplumsal şiddetin kanıksanıp yaygınlaşmasındaki rolü de her zamankinden daha fazla sorgulanıp, tartışılır hale gelmiştir. Şiddetin artmasında medyanın rolüne ilişkin birçok eleştirel bakış açısı geliștirilmiştir. Sinema da, kendine özgü anlatım süreci ile eleştirel bakış açısına katkı sağlamaktadır. Bu çalışma kapsamında Natural Born Killers filminin şiddet toplumuna ve medyanın buna katkısına yönelik geliştirdiği eleștirel bakış açısı incelenmiştir. Çalışmada göstergebilimsel çözümleme yöntemi uygulanmıştır.

Anahtar Kelimeler: Şiddet, Şiddet Toplumu, Medya, Sinema, Göstergebilim. 


\title{
A Cinematic Approach of Criticisim of Mediatic Violence: Natural Born Killers
}

\author{
Hakan Sağlam (PhD.) \\ mydreams_04@hotmail.com \\ Orcid: 0000-0003-0433-6620
}

Date Received: 27.06.2018

Date Accepted: 18.12.2018

Date Published: 21.01.2019

\begin{abstract}
Almost all the social scientists agreed that the dizzying technological development of our age brings with it a large number of social problems and these problems continue to grow day by day aside from being solved. Violence with its roots which extent down to the deepest points of human history maintain own place in the social agenda continiously. With the emergence and rapid spread of social media, the role of the media about adoption and spreading of social violence has become more questionable and debatable than ever. Many critical perspectives have been developed on the role of the media related to increasing violence. Cinema also contributes to critical point of view with its own narrative process. Within the scope of this study, inspected critical view point of Natural Born Killers movie in related to developing about violence society and media's contribution to it. Semiological analysis method was applied in the study.
\end{abstract}

Keywords: Violence, Violence Society, Media, Cinema, Semiology. 


\section{Giriş}

Niteliği gereği çok boyutlu ve karmaşık özellikler taşıyan şiddetin yaygınlaşmasında kitle iletişim araçlarının önemli faktörlerden biri olduğu geniş ölçüde kabul edilmektedir.

Şiddetin toplumsal dokuda bir kanser gibi yayılmasındaki faktörler ele alınırken artık medyanın rolünü sorgulamama olasılığı kalmamıștır. Kimi sosyal bilimciler şiddetin toplumsal boyutta artmasında medyanın rolünün abartıldığını düşünse de araştırmacıların önemli bir kısmı medyanın şiddeti özendirdiğini düşünmektedir. Gerçekten de medya, toplumsal şiddetin artmasında önemli bir aktör olabilir mi? Yoksa medya topluma beklediklerini sunan basit bir aracıdan ya da toplumun görüntüsünü yansıtan bir aynadan mı ibarettir? Medyanın rolü abartılıyor ya da medya bir günah keçisi olarak lanse ediliyor olabilir mi? Şiddet-medya ilişkisi bağlamında bu soruların cevaplanması kolay değildir ve konu sadece akademisyen ve bilim insanlarının ilgisiyle de sınırlı değildir.

Bir anlatı türü olarak sinemada da "şiddet" geniş ölçüde işlenir. Hayata dair ne varsa kendine konu edinen sinemanın, toplumsal dokunun yer yerine sızmış olan şiddete değinmemesi beklenemez. Ancak sinemanın şiddete yaklaşımının öncelikle sanatsal kaygılarla biçimlendiği göz ardı edilmemelidir. $\mathrm{Bu}$ nedenle şiddetin artmasında medyanın rolünü işleyen bir sinema filmi olsa olsa içe dönük bir bakışın sanatsal bir dille ifadesi olarak görülebilir.

Sinema tarihinde şiddetin kitle iletişim araçlarıyla ilgisini işleyen başta gelen yapım, 1994 yılında gösterime giren ve Oliver Stone tarafından yönetilen "Katil Doğanlar" (Natural Born Killers) filmidir. Bu çalışma kapsamında "Natural Born Killers" filminin şiddet toplumuna yönelik medya eleştirisi çerçevesinde geliştirdiği anlatı; göstergebilimsel yöntem kullanılarak çözümlenmiş ve filmde anlam üretim sürecinin aşamaları belirlenmeye çalışılmıştır.

Saussure ve Pierce'nin çalışmalarından yola çıkılarak geliştirilen göstergebilim, iletilerin aktarımı ile değil, anlamların üretimi ve değişimi ile ilgilenir (Fiske, 2003, 239). Göstergebilim (semiyotik) dilyetisini gözlemlenecek tek katmanlı bir nesne olarak değil; oluşturulmuş, inşa edilmiş, anlamsal katmanlardan kurulu bir bütün olarak görür ve onun üretiliş biçimini anlamak için kuruluşunu, oluşum sürecini yeniden kavramaya ve yeniden anlamlandırmaya çalışır (Rifat, 2009, 15).

Göstergebilim, anlatının içerik düzlemindeki biçiminin üç değişik düzeyde çözümlenebileceğini benimser. Bunlar; söylemsel düzey, anlatısal (dizimsel) düzey ve mantıksal/anlamsal düzey olarak yüzeyden derine doğru sıralanmaktadır. Söylemsel düzeyde ilk olarak kişiler, kişilerin rolleri ve olay örgüsünün zaman ve uzamı belirlenir. Anlatısal (dizimsel) aşamada sahneler arası geçişler tespit edilir. Sahneler arasındaki ayrımı bulmak ile kastedilen, sahnelerin geçirdiği dönüşümün tespit edilmesidir; dönüşümü bulmak ise anlamın düzenleniş doğrultusunu yakalamaktır. Bir anlatının oluşması en azından bir başlangıç durumu ile bir sonuç durumunun ve bu iki durum arasındaki temel dönüşümü gerçekleştirecek bir dönüştürücü öznenin varlığını gerektirir. Mantıksal/anlamsal düzeyi olușturan dizisel aşama ise kesitlerin birbirini bütünleyen benzerler ile birbirinden ayrılmasını gerektiren zıtlıkların belirlenmesine dayanır. Göstergebilim çözümlemesinin nihai amacı derindeki anlamın ortaya çıkarılmasıdır (Rifat, 2007, 35-41). 
Çalışma kapsamında göstergebilimsel çözümleme aşamalarından dizimsel ve dizisel çözümleme yöntemleri “Natural Born Killers” filmine uygulanmıştır.

\section{Şiddetin Kavramsal Çerçevesi}

Şiddet sözcügü Büyük Larousse Ansiklopedisi'nde $(1986,11073)$ altı ayrı anlamda kullanılmaktadır.

1. Bir olgunu gücü, yoğunluğu, sertliği, yeğinlik: ışığın şiddeti, depremin şiddeti.

2. Yoğun, sert ve çoğu zaman yıkıcı bir güçle kendini ya da etkisini gösteren bir şeyin özelliği: bir çarpmanın, bir darbenin şiddeti.

3. Soyut bir şeyin gücü, yoğunluğu: şiddeti gün geçtikçe artan ekonomik bir bunalım yaşamak.

4. Beden gücünün kötüye kullanılması, silahlı etkinlikler ve aşırı bir saldırganlık özelliği taşıyan ilişkilerle belirginleșen edimlerin tümü: kaba kuvvet.

5. Bir duygunun aşırılığı, taşkınlığı: tutkuların şiddeti.

6. Şiddet göstermek: sert ve kaba bir biçimde davranmak.

Dar anlamıyla şiddet, fiziksel şiddete işaret ederken; geniş anlamıyla şiddet, şiddetin fiziki ve psikolojik her yönünü kapsar.

Fiziksel şiddet: Dar anlamıyla şiddettanımında, tartışılmazveölçülebilir nitelikleriyle, fiziksel şiddet tektir. İnsanların bedensel bütünlüğüne karşı dışarıdan yöneltilen, sert ve acı verici bir edimdir. Hukuk dilinde 'eşhasa (şahıslara) karşı cürümler" diye nitelendirilir (Ünsal, 2007, 31).

Dolaylı şiddeti oldukça geniş bir kapsamda ele alan Ünsal (2007, 33); insan üzerindeki fiziksel ve ruhsal etkileri somut bir biçimde hissedilen çeşitli baskıları (ekonomik sorunlardan çevre kirliliği ve gürültüye kadar) şiddet kategorisine dâhil etmektedir.

Şiddet, modern dünyada evrensel açıdan en ciddi toplumsal sorunlardan birisidir ve sindirme amaçlı güç kullanma anlamına gelir. Şiddeti uygulayan, karşısındakini denetim altına alma hedefindedir. Genel kabul gören tanımı ise başkalarını incitmek, kontrol etmek veya sindirmek için fiziksel güç kullanmak ya da bu şekilde davranarak zarar vermek, yıkıcı davranıșta bulunmaktır (Kıroğlu, 2006, 19).

Şiddetin tanımı Sosyal Bilimler Ansiklopedisi'nde kısa ve basittir: "Kişisel veya grupsal amaçlar uğruna fiziksel baskı yöntemlerine başvurulması”. Ama bu tanım, şiddetin hem sebeplerinin, hem de amaçlarının çeşitliliğini açıklamada oldukça yetersizdir. İște bu yüzden, daha geniş bir tanımlama öneriliyor: "Bir kiși veya topluluğun, fiziksel ve ahlaki bütünlüğüne, mülkiyetine, kültürel veya sembolik değerlerine karşı herhangi bir birey, grup ya da örgütlü bütünlük tarafından verilen zarar veya fiziksel ya da psikolojik acı". Bu tanıma göre şiddet, çatışan çıkarları olan tarafların arasındaki sosyal ilişkiden kaynaklanmaktadır (Ergil, 2001, 399).

\section{Psiko-Sosyal Boyutlarıyla Şiddet}

K. Lorenz "Saldırganlık Üzerine" adlı kitabında şiddetin esas olarak dış uyaranlara karşı bir tepki değil, insanın içinde gömülü ve serbest kalmaya çabalayan bir durum olduğunu söylemiştir. Dış uyaranlar yeterli olsun olmasın, anlamını bulacak bir uyarılma durumudur. Freud ile aynı tezi desteklemektedir. Savaşta, suçta, kişisel tartışmalarda ve her türlü yıkıcı, sadistçe harekette açığa çıkan şiddet; boşalma 
yolları arayan ve kendini açığa çıkarmak için uygun bir ortam olmasını bekleyen, katılımsal olarak programlanmış, doğuştan bir içgüdüden kaynaklanır (Kocabaşoğlu, Savrun ve Konuk, 2000, 28).

Freud, içgüdüsel dürtü görüşünde sonuna kadar ısrar etti. İçgüdülerin bütün etkinliklerinin nihai sebebi olduğunu yazdı. Organizma ne kadar ilkelse, davranıș o kadar içgüdüseldir. Organizma ne kadar gelişmişse, içgüdüsel davranış da o kadar bir oluşumun programı haline dönüşür, yani özel, önceden kararlaştırılmış bir rutin olmaktan çlkar. Bir başka deyişle, organizma ne kadar gelişmişse, öğrenme için o kadar geniş olanak vardır. İnsan dahil tüm memelilerde bu öğrenme hareketi duygulanımlarla güdülenir. Duygulanım, Freud'un düşündüğü gibi içgüdünün bilinç üzerindeki basit bir tezahürü değildir. Duygulanım daha çok davranışın göreli olarak bağımsız bir kontrol sistemidir. Duygulanım tepkileri, altbeyin ve otonomik sinir sistemi aracılığıyla oluşurlar. Basit olarak söylemek gerekirse, duygulanımlar, duyusal bir uyaranın sıklığı ve şiddetine karşı oluşan bir tepkiyi temsil ederler (Erten ve Ardall, 2007, 145).

Brenner'in de vurguladığı gibi, psikolojik bir olay, sadece yaşantının değil, aynı zamanda merkezi sinir sistemi faaliyetinin de bir ürünüdür. Dürtüler, klinik bilgilerimiz ve doğrudan gözlemlerimizle bildiğimiz kadarı ile sadece doğuştan gelen basit verilerin ötesinde olan psikolojik olaylardır (Erten ve Ardalı, 2007, 157).

Freud, "gerçek ruhsal varlık" dediği "id" üzerinde görüşlerini yoğunlaştırır. Ona göre her organizmada cinsiyet ve kendini koruma içgüdülerinden oluşan "yaşam içgüdüsü" ve buna karşılık da "ölüm içgüdüsü” vardır. Freud'a göre yaşam ve ölüm içgüdüleri devamlı olarak birbirleriyle savaşırlar. İnsan ölüm ve yaşam içgüdülerinin birbirlerine karşı savaştıkları bir alandan öte bir şey değildir. Bu iki farklı içgüdü her insanda bulunur. Freud ölüm içgüdüsünün en önemli türevinin saldırganlık içgüdüsü olduğunu ve insanın kendine yönelik olan yıkıcı eğilimlerinden kaynaklandığını ve çoğu insanda bu içgüdünün yaşam içgüdüsü tarafından engellendiğini belirtir. Bu iki içgüdü birbiri tarafından engellendiği gibi birbirlerinin yerine de geçebilirler. Sevgi nefretin, nefret sevginin yerini alabilir. Kişi sevdiği şeyden nefret edebilir. Onu özdeşleştirdiği için kendini yok ederek onu da yok edeceğine inanır. Biyolojik öğelere birincil önemi yükleyen Freud, sosyal faktörleri dikkate almadığı için eleştirilmiştir (Oktik, 2008, 207-208).

Edinilmiş bir davranış biçimi olarak saldırganlık da değişime uğramaya açıktır. Bireyler saldırgan davranmayı nasıl öğrenebiliyorlar ve dış (veya hatta iç) koşullarla teşvik edilebiliyorsa, aynı biçimde bu bireylere saldırgan olmayan tarzda davranmak ve başkalarına zarar vermekten kaçınmak da öğretilebilir. Amaca uygun adımlar atıldığı takdirde saldırganlık denetim altına alınabilir (Archer ve Gartner, 2007, 248).

Ebeveynlerin birbirlerine ve çocuğa yönelik şiddet davranışları, çocuğa sonraki yaşamında aynı şekilde şiddete başvuran bir erişkin olması için önemli bir model olmaktadır. Çocukken fiziksel yönden örselenmiş erişkinlerin şiddet davranışı açısından yüksek bir risk grubu oluşturdukları, yapılan araştırmalarla açıklığa kavuşturulmuştur (Göka, 1989, 26).

Minnesota Üniversitesi'nden Alan Sroufe'nin yirmi üç yıldır yürüttüğü araştırma, şiddet ve suça yatkınlık davranışlarının gelişimini inceliyor. Araştırma ekibinde çalışan Byron Egeland, araştırmanın şiddet ve suça yatkınlık konusunda, insanların 
doğuştan gelen özelliklerinin çok da önem taşımadığına işaret ettiğini, insanların sorunlarını şiddete yönelerek çözme davranışlarının gelişmesinde en önemli etmenin ailedeki yetiştirme koşulları olduğunu belirtiyor (Zülal ve Yüce, 2001, 37).

Aile içinde şiddetin yönü en çok kadın ve çocuğa doğru olmakla beraber, aile içindeki iktidar ilişkilerinde belirlenerek, güçlüden güçsüze yönelik olduğunu ortaya çıkarıyor. Şiddetin meşru görülmesi önce ailede ve sonra toplumda tekrar tekrar üretilmesine ve bir sorun çözme yöntemi olarak kuşaktan kuşağa aktarılmasına yol açıyor (Zülal ve Yüce, 2001, 36).

Şiddet olgusunun çok önemli bir yönü de, toplum içinde ve toplum tarafından nasıl sunulduğu ve kabul gördügüüür. Çünkü kabul gören veya makul görülen şiddet, "meşru"dur. Şiddet, genellikle bir yaşam biçimi olarak benimseniyorsa toplumsal davranışlar listesinde yer almakla kalmaz, sorun çözmenin bir aracı olarak da onay görür. Gittikçe büyüyen bir duyarsızlıkla șiddet, hayatın her alanına sızar, baskıcı yönetim biçimlerinden (siyasetten) bağımsız olarak, bir şiddet kültürü yaratır. Toplumun alt kademelerinde, "şiddetten başka hiçbir şey başarı getirmez" görüşü hakim olursa şiddet her alana yayılır. Birey, kendinin önemsiz ve bu önemsizliğinin değişmez olduğuna ne kadar çok inanırsa şiddetin dozu o kadar artabilir. Kendisini önemsiz hisseden birey, sıradanlığın panzehiri olan şiddet ile hayatını olumsuz kılan her şeyi yok edebileceğine inanır. Önemsizlik hissi çok tehlikelidir. İnsanlar, zorla etkisizleştirildiklerine veya olumsuz koşullardan çıkış için çok az şans tanındığına inanıyorlarsa kendilerini yenik ve çaresiz hissetmeleri olağandır. Bu duyguların yarattığı umutsuzlukla beslenen yığınların, için için kaynayan öfkesini uzun süre bastırmak oldukça zordur (Ergil, 2001, 41).

\section{Medya ve Şiddetin Popülerleştirilmesi}

Postman'a göre elektronik iletişimin keşfinden sonra büyüklerin dünyasına ait enformasyonun çocuklara ulaşmasını önlemek imkânsızlaşmıştır. Daha önceki devirlerde ise yazılı enformasyon hem ulaşılması daha zor olduğundan, hem de anlaşılması için okuma yazma bilmenin yanında belli bir kültür seviyesine ulaşmış olmayı da gerektirdiğinden, çocuklar tarafından kolay kolay ele geçirilememekteydi. Böylece çocuklar (en azından matbaanın keşfinden, TV'nin yaygınlaşmasına kadar) kendilerine zararlı olduğu varsayılan büyüklerin dünyasına ait enformasyondan korunmuş olmaktaydılar. TV yaygınlaştığından beri ise büyüklerin dünyasına ait olan ve en başta seks ve şiddet öğeleri barındıran filmler ve programlar çocuklar için bir düğmeye basılarak erişilecek kadar yakın hale gelmiştir. Bu tür programların henüz iyiyle kötüyü ayırt edemeyecek durumdaki genç dimağlarda derin etkiler bırakması son derece doğaldır (Turam, 2007, 392).

Şiddetin çocuk ve gencin yaşamına "doğal" olarak girmesi şaşırtıcı bir biçimde sıradan süreçleri izler. Çocukluğun ilk evrelerinde televizyonda izlenen çizgi filmlerden, çocuk programlarına, haberlere dek, çocuklar şiddetle iç içe yaşamaktadır. Böylesine yoğunlukta şiddet imgesiyle yüklenen çocuklar da şiddeti oyun gibi yaşamakta ve şiddetin uygulayıcısı olmayı kolaylıkla benimseyebilmektedir (Gümüşoğlu, 2006, 101).

Korku ve dehşet saçan ekranlardaki sanal şiddet sunumları, bir boşalma, arınma aracına dönüşmekte, giderek alışkanlıkla birleşerek şiddetin, suçun kanıksandığı, onay gördüğü ve ona yönelimin kolaylaştığı sert bir iklime yol açmaktadır (Çakır, 2008, 167). 
Televizyon çocukları ve gençleri her gün ve her gece binlerce şiddet, cinsellik ya da cinsel şiddet örüntüsünün edilgen alıcısı haline getiriyor. Çocuk bu görüntüleri bir ekran karşısında bir ışık ve ses gösterisiyle monolog halinde izliyor olsa bile, izlediği görüntüler acımasız bir şekilde beynine işliyor, imgelemi üzerinde silinmez izler bırakıyor. Üçle beş yaşları arasında, yani beynin bilişsel ve dilsel gelişiminin en önemli döneminde, bir çocuk haftada en az 28 saat televizyon izliyor. İlkokul öğrencileri için ortalama izleme süresi haftada 25 saat, lise öğrencileri içinse haftada 28 saattir. Bir çocuk beş yaşına geldiğinde artık 6000 saat televizyon seyretmiş olacaktır. Televizyonun etkilerini düşünecek olursak, aynı istatistiği farklı bir şekilde de dile getirebiliriz: Beş yaşına gelen ortalama bir çocuk, 6000 saat programlanmıştır. Bu alışkanlık çocuğu tümüyle zayıf düşürür. Sağlıklı bir insan olabilmek için gereksindiği doğal ve duygusal gelişiminin kısa devre yapmasına yol açar; kendi sesinin gelişimini engeller ve düş gücünün önüne set çeker. Kimi nöroanatomistler aşırı televizyon izlemenin -günde dört ya da beş saatten fazla- ciddi bilişsel yitime neden olduğunu savunuyor (Sanders, 2010, 46).

Yapılan araştırmalarda, medyanın yarattığı "sosyal gerçekliğin" şiddet ile ilgili olarak şu görünümleri tespit edilmiştir:

1. Şiddet olgusu, medyanın en önemli içerik unsurlarından birisi olmaya devam etmektedir.

2. Sergilenen şiddetin yöneldiği kişiler çoğunlukla kadınlardır. ABD medyalarının sergilediği şiddetin diğer hedefleri; renkli ırktan insanlar, yabancılar, alt ve orta sinıftan insanlardır.

3. Medyayı (özellikle televizyonu) aşırı izleyenler "şiddet dolu bir dünya" algılamakta ve bu durumdan korku duymaktadır (Oktay, 1996, 157).

Pearce, bütün yaşamı boyunca çocuk gelişimi konusunda yazılar yazmıştır. Son yıllarda özellikle beynin limbik sinir yapısıyla televizyon arasındaki ilişki üzerinde durmaktadır. Araştırmalarının sonuçları okuryazarlık açısından son derece önemlidir: Televizyon, çocuk beyninin kendi imgelerini üretmeye başlaması gerektiği dönemde, çocukların beynine çeşitli görüntülerle sel gibi akmaktadır. Öykü anlatmak, çocuğa beynimizin üçlü sisteminin her yönünü kapsayan bir imge yaratma etkinliğine girişmesi için uyarı sağlarken televizyon, çocuk beynine çift yönlü tek bir etki vererek hem uyarı hem de tepki sunar. Televizyonun en büyük tehlikesi de burada yatmaktadır. Televizyon, beyni, beynin söz ya da müziğe cevap olarak kendisinin üretmesi gereken tepkinin taklidiyle doldurur. Sonuç olarak, akılla çevre arasında kurulması gereken ikili yapısal ilişki kurulamaz; pek az metaforik imge oluşur; beynin üst kortikal bölgesinin az bir kısmı işler hale gelir. (Sanders, 2010, 47-48). Televizyonun bir diğer sinsi etkisi ise alışkanlık yaratmasıdır.

Sosyal öğrenme kuramı, son 40 yıldır bilimsel araştırmalarla desteklenen, değişime açık ve bu açıdan da güçlü bir kuramdır. Bu kuram temel alınacak olursa, bir toplumda televizyon programlarının, bilgisayar oyunlarının ya da çocukların davranış biçimlerini öğrenebilecekleri diğer kaynakların içeriğinin hassaslıkla denetlenmesi gerekiyor (Zülal ve Yüce, 2001, 39).

Elbette medyada şiddet içeriklerine maruz kalan her çocuğun hemen şiddet sahnelerini taklit edip birer şiddet uygulayıcısına dönüşeceği savunulamaz. Ancak çocuğun bilișsel dünyasının oluşumunda medya, günümüzde kültürün rolüne 
ciddi anlamda rakip olmuştur. Televizyon kanallarında ve internette duygusal ve cinsel gelişimleri için zararlı filmler izleyen ve yaş denetimi olmadan şiddet içerikli oyunlar oynayan çocukların nasıl bir yetişkinliğe hazırlandığı duyarlı her anne-baba için bir endişe kaynağıdır. Çünkü şiddet imgesiyle yüklenen ve zamanla şiddeti bir oyun gibi algılamaya başlayan çocukların şiddetin uygulayıcısı olma olasılığı da artmaktadır. Toplumda şiddet eğilimli bireylerin artışı suçun kanıksandığı ve onay gördüğü bir iklimin oluşmasına yol açarak toplumsal dokuyu bozmakta ve yarattığ mağduriyetlerle hukuk dişılığa hizmet etmektedir.

\section{Natural Born Killers (Katil Doğanlar) Filminin Çözümlenmesi Çalışmanın Yöntemi}

Bir anlatı türü olarak sinema filmlerinin çözümlenmesi farklı yöntemlerle yapılabilmektedir. Bu çalışma kapsamında Natural Born Killers filminin toplumsal şiddetin artışında medyanın rolüne ilişkin geliştirdiği anlatının çözümlenmesinde göstergebilimsel yöntemden yararlanılmıştır. Göstergebilimsel çözümleme aşamalarından dizimsel ve dizisel çözümleme yöntemlerinin Natural Born Killers filmine uygulanmasıyla filmdeki anlam üretim sürecinin aşamaları belirlenmeye çalışılmıștır.

\section{Filmin Künyesi}

Katil Doğanlar (İngilizce özgün adı: Natural Born Killers) 1994 yapımı, Oliver Stone tarafından yönetilmiş ve başrollerinde Juliette Lewis ve Woody Harrelson'ın oynadığı bir filmdir. Rodney Dangerfield, Robert Downey Jr., Tom Sizemore ve Tommy Lee Jones yardımcı karakterleri canlandırmışlardır. Filmin öyküsü Quentin Tarantino'ya aitken, senaryosu Oliver Stone, Dave Veloz ve Richard Rutowski'ye aittir. 118 dakikalık filmde iki katilin hikâyesi anlatılmaktadır (IMDB, 2018).

\section{Filmin Karakterleri ve Toplumsal Algıları}

Film dört ana karakter üzerinden inşa edilmiştir. İki katilden biri olan Mallory Knox (Juliette Lewis) kendisine cinsel tacizde bulunmuş babası (Rodney Dangerfield), annesi ve hiç geçinemediği küçük kardeşi Kevin ile birlikte yaşamaktadır. Mallory, babasının sapkın davranışlarının getirdiği psikolojik hasarlar dolayısıyla yaşadıklarına bir tepki olarak geliştirdiği asi ve saldırgan bir kişilik yapısına sahiptir. Bu kişilik yapısı Mickey'in gerek sözleri ve davranışları gerekse giyim kuşamı ile kendini açığa vurmaktadır. Hayata karşı agresif tutumu, Mallory'i şiddete eğilimli hale getirmiş, onu patlamaya hazır bir barut gibi nefret duygularını boşaltacağı bir arayışa yönlendirmiştir. Filmin ilerleyen sahnelerinde de görülebileceği üzere Mickey (Woody Harrelson) ile tanışmasıyla eyleme geçmekte hiç vakit kaybetmeyecektir.

Filmdeki diğer katil Mallory'in sevgilisi Mickey'dir (Woody Harrelson). Mallory ile ilk karşılaşmalarında üzeri kanlar içinde Mallory'in evine et getiren bir kasap çalışanı olarak betimlenen Mickey, adeta Mallory'in erkek versiyonu ya da ruh ikizi gibidir. Kin ve nefret yüklü, son derece acımasız ve şiddet eğilimli bir karakter olan Mickey aynı Mallory gibi anlık tepkilerle cinayet işleyebilen sadist bir karakterdir. Çocukluğunda Mallory gibi ağır bir travma yaşamasa da Mallory'in de babasının ölümüne şahit olduğu anlaşılmaktadır. Filmde Mickey kendisini anlatırken, şiddetin içinden geldiğini, babasının da büyükbabasının da kendisi gibi şiddet eğilimli olduğunu ve bunun kendisinin kaderi olduğunu söylemektedir. 
Filmdeki üçüncü temel karakter Mallory ve Mickey'i yakalayan polis memuru Jack Scagnetti (Tommy Lee Jones)'tir. Mallory ve Mickey'i yakalayarak ünlü olmayı bir saplantı haline getiren Scagnetti sonunda bunu başararak bir medya fenomeni olarak TV'lere çıkar ve kitap yazar. Mallory ve Mickey ile kıyaslanamayacak boyutlarda da olsa kendisinin de bir takım sadist eğilimleri olduğu anlaşılan Scagnetti, Mallory'e karşı hem nefret beslemekte hem de cinsel ilgi duymaktadır. Hayat hikâyesinden anlaşıldığı kadarıyla Scagnetti, küçük bir çocukken annesinin bir katil tarafından öldürülüşüne tanık olmuştur. Kendi ifadesiyle Scagnetti, o günden sonra psikopatlara karşı ilgi duymaktadır.

Filmdeki dördüncü temel karakter olan Wayne Gale (Robert Downey Jr.) ABD’deki seri katilleri ve cinayetlerini konu alan American Maniacs adlı yapımcılı̆̆ını üstlendiği bir televizyon programıyla, toplumsal şiddeti reyting amaciyla seyirlik bir eğlence haline dönüştüren bir medya çalışanı prototipi olarak karşımıza çıkmaktadır. Mallory ve Mickey'in işledikleri tüm cinayetleri sansasyonel bir şekilde magazinleștirerek izleyicilere sunan Wayne Gale, ikiyüzlü bir tutum sergileyerek kendini kimi zaman katil çiftin yanında kimi zamansa karşısında konumlandırmaktadır. Filmde en dikkat çekici noktalardan biri, medya eleştirisinin çoğu kez Wayne Gale'ın şahsında somutlaştırılarak yapılmasıdır.

\section{Filmin Öyküsü}

Oliver Stone'un filmi, büyük bütçeli bir Hollywood filmidir. Stone, bu filmi çekmeden önce iki Oscar kazanmış bir yönetmendi.

Aslında filmin öyküsü çok basittir. Mickey ye Mallory Knox çifti ABD’nin güneybatısında yolculuk etmektedirler. Bu yolculuksırasında tam 50 kişiyi öldürürler. Polis enselerindedir. Polis müdürü Jack Scagnetti ve televizyon yorumcusu Wayne Gayle bu seri cinayetler işleyen sevgililer sayesinde ünlü olmayı düşünmektedirler. Haberci, American Maniacs adlı bir TV-Reality-Show'un yorumcusudur. Bu hedef, Mickey ile Mallory'i birer süperstar yapmaya yetecektir. Katillerin gerek tutuklanması gerekse daha sonra onlarla cezaevinde yapılan TV röportajı, sansasyonel medya canlı programlarının tipik örneklerinden birini sunar. Cezaevinde bir isyan patlak verince de, iki katil bunu fırsat bilip kaçmaya çalışırlar. Kaçarken arkalarında tam bir kan gölü bırakırlar; üstelik televizyoncu da bu eylemlerde onlardan yana aktif rol alır. Daha sonra Mickey ile Mallory artık ona ihtiyaçları kalmadığı, yeterince ünlü oldukları için onu da öldürürler. Filmin sonunda bir sürü çocuğun ortasında hamile Mallory ile Mickey, mutlu ve huzurlu, karavanlarıyla yine ülkeyi dolaşmaktadır (Körte, 2006, 92-93).

\section{Dizimsel Çözümleme/Kesitler}

\section{Kesit-1: Giriş}

Filmin başlangıcında renkli ve siyah-beyaz geçişlerle hızla akan sahnelerle yılan, şahin, akrep gibi çeşitli hayvan görüntüleri ekrana gelir. Başta yılan olmak üzere yırtıcı ve zehirli hayvanların filmin pek çok yerinde kullanıldığı görülmektedir.

Filmin başlangıcını oluşturan ilk kesiti, bir zaman kayması oluşturmaktadır. Filmin iki başrol karakteri Mickey ve Mallory çiftinin tanışmaları ikinci kesitte işlendiği için ilk kesit ardından gelen kesite göre bir zaman kaymasıdır. Zira birinci kesit işleniş itibariyle üçüncü kesitle paralellik gösterdiğinden yönetmen tarafından ilgi çekiciliği arttırmak için kesitler arası oymanın kasten yapıldığı düşünülebilir. 
Mickey ve Mallory, bir barda ayrı olarak oturmuş içki içmektedir. Mallory kendisiyle dans eden adamla, adamın kendisine sarkması üzerine dövüșür ve ardından işe Mickey müdahale eder. Mallory ve Mickey, bardaki tek kişi hariç diğerlerini öldürürler. Öldürme görüntüleri bir video müzik klibi havasında yavaşlatılmış görüntülerle verilir. Kalan kişiye Mallory: "Sana sorduklarında Mickey ve Mallory Knox'un yaptığını söyle." der. İkilinin cinayetleri medyatik olma hevesiyle yaptıklarının işaretleri filmin daha ilk dakikalarında verilmektedir.

Çift, işledikleri cinayetlerin ardından birbirlerini sevdiklerini söylerler. Dans ettikleri yerde ekrana havai fișeklerle kutlama görüntüleri gelir. Ardından ekrana ikilinin işlediği cinayetleri konu eden gazete kupürleri, atom bombası, dövüşen hayvan görüntüleri gibi şiddetle ilişkilendirilebilecek görüntüler yansır. Mallory, Mickey'e: "Bizler birer meleğiz." der. İkilinin kavramlarla oynama çabası filmin pek çok yerinde görülmektedir.

\section{Kesit-2: Başlangıç Durumu}

Filmin ikinci kesitinde Mallory ile Mickey'in seri cinayetlere başlamadan önceki durumları işlenmektedir. Mallory'in çocukluğundan itibaren annesine de çok kötü davranan sadist babasının cinsel tacizine uğradığı anlaşılmaktadır. Bu acı gerçeklik filmde bir sitcom havası içinde verilmekte, trajedinin aktarılmasında alkışlamalar ve gülme efektleri kullanılmaktadır. Trajik olayı magazinleștirerek seyirlik hale getiren medya için filmdeki ilk ciddi eleştiri de burada başlar. Buna benzer bir örnek Mallory'in babasının, annesine, küçük kardeşi Kevin'in dünyaya gelişi ile ilgili "Bir gece sarhoştum ve kızını sen sandım." demesi üzerine Kevin'in "Yani Mallory benim annem mi?" deyişini gülme efektleri ile verilen sahnede de görülmektedir. Mallory'in şiddete eğiliminin psikolojik altyapısı hakkında fikir edinilen başlangıç durumu, medyaya karşı eleştirel bir bakış açısıyla ișlenmektedir.

Filmde sadist ikilinin ilk tanışması yine bir sitcom havasında verilmektedir. Babası tarafından kötü muamele gören Mallory için Mickey adeta bir kurtarıcı, bir kahraman gibidir. Burada, Mallory'in gözünde kötü bir figüre (babasına) karşı ondan daha acımasız olan başka bir kötü figür (Mickey) kahramanlaştırılmıştır. Ayrıca Mallory'in, Mickey'e babasının kendisini taciz ettiğini ve buna dayanamadığı söylemesi Mallory'in de kendi gerçekliğinin bir mağduru olduğunu göstermektedir.

Mallory'in evine elinde et yığınlarıyla üzeri kanlar içinde bir kasap çalışanı olarak giren Mickey -ki bu meslek Mickey için bilinçli olarak seçilmiştir- ile Mallory ilk görüşte birbirlerine aşık olurlar. Bir suç işleyip hapse giren ve sonra hapisten kaçarak Mallory'in evine gelen Mickey, Mallory ile birlikte önce Mallory'in babasını kafasını akvaryuma sokarak boğmak ve ardından annesini yatağa bağlayarak yakmak suretiyle feci şekilde öldürürler. Mallory'in annesine son sözü babasını kastederek "Ona hiç engel olmadın." olur. Mallory erkek kardeşi Kevin'e sadece "Özgürsün." der ve Mickey ile birlikte onu öylece kaderine teslim edip giderler. Şiddetin bencil, acımasız ve soğuk yüzü olan Mallory, öz kardeşinin dahi gözünün yaşına bakmaz.

Mickey ve Mallory işledikleri vahşetten büyük haz duyar, adeta kendilerinden geçerler. İkilinin ruh halleri ekrana getirilen havai fişek görüntüleri ile temsil edilir. Mallory artık yepyeni bir kadın olduğunu söyler. İşlediği cinayetlerle yeni bir kimlik edindiğini düşünen Mallory kendini güçlü hissetmektedir. Geçmişinde mağdur olan Mallory, geçmişinden şiddet yoluyla intikam almaya girişmiştir. Ruh dünyasının 
yenilendiğini düşünen Mallory, yeni kimliği için yeni kıyafetler istemektedir. Mickey ile Mallory, geçmiş geride kaldı diyerek, eski eşyalarını ve kıyafetlerini uçurumdan aşağıya atarlar.

Mickey, "Şimdi büyüme zamanı. Cehennem bizi bekliyor." der. İkili için cinayet işlemek olgunlaşmaktır. İkilinin cinayet ve şiddet kavramlarına olumlu değerler atfettikleri görülür.

Mickey, Mallory'e evlenme teklif eder ve Mallory kabul eder. Mallory'in "Nerede evlenelim?" sorusuna Mickey "Bizim kilisemiz burası." diyerek köprünün üzerindeki açıklık alanı gösterir. Mickey, toplum dışı konumlarının farkındadır ve bu onlar için bir intikam ve övünç kaynağıdır. Mallory ve Mickey, toplumsal olan her şeyden nefret ederler. Mickey önce kendi elini sonra da Mallory'inkini kesip birleștirir. Kanlar uçurumdan aşağıya nehre akıtılır. Kan, ikilinin en sevdiği sıvıdır: Yaşam veren değil, alan olarak.

Mickey'in Mallory'e taktığı yüzükte iç içe geçmiş iki yılan figürü görülür. Bu iki yılan Mickey ve Mallory'in birlikteliğini simgeler. Mickey yanlarından geçen bir arabaya sinirlenip "Düğün günümüzde kimseyi öldürmeyeceğim.” der. İkili, olanca vahşeti içinde yer yer esprili karakterler olarak sunulur.

Mickey, Mallory’e yüzüğü taktığında “Kendi dünyamın Tanrısı'nın bana verdiği yetkiye dayanarak bizi karı-koca ilan ediyorum." der. Mickey, kendi Tanrı'sının toplumun genel kabul gördüğü Tanrı'dan farklı olduğunun farkındadır. Onun Tanrı'sı onlara iyi insanlar olmalarını ögütlemez. Romantik bir müzik çalar ve ikilinin ne kadar mutlu olduğu gösterilir. Mickey ve Mallory kendi gerçeklikleri içinde romantik ve mutlu olabilmektedir. Zaten onlar için hayatta tek önemli olan kendileridir.

\section{Kesit-3: Şiddetin Medyatik Fenomenizmi}

Diş sesin “Bundan sonra Mickey ve Mallory'i hiç kimse durduramad. Pek çok suç işlediler." dediği duyulur. Bu, ikilinin birer medya fenomeni haline gelmelerinin ilk işaretleridir.

Amerikalı Manyaklar programının yapımcı ve yönetmeni Wayne Gale, ikiliyi kahramanlaştırarak haber yapmaktadır. Mickey ve Mallory'in on iki polisi öldürüşünü dramatize bir şekilde sunmaktadır. Görüntüde gözü yaşlı bir polis memuru, arkadaşının Mickey ve Mallory tarafından öldürüşünü anlatır. Burada, hem reyting için kişisel trajedileri istismar edişine yönelik medyaya eleștirel bir yaklaşım sergilenmekte hem de şiddet içeren programlara ilgisi dolayısıyla izleyiciler eleştirilmektedir.

Görüntülü haberde Mallory, bronz madalyalı bir maratoncuyu vurur ve "Hep bunlardan birine ateş etmek istemişimdir. Bunları vurmak kolay değil." der. İkili için insan öldürmek, ormanda kuş avlamaktan farksızdır.

Programın yapımcılarından biri, Mickey ve Mallory'in aynı görüntülerinin tekrar tekrar verilmesi hakkında şöyle der: "Tekrar hep işe yarar. Bu aptal insanlar bir şey hatırlar mı sanıyorsun? Vücuda zararlı besinler gibi. Zaman öldürücü. Değersiz." Burada medyanın hem izleyicisine yönelik onu değersiz gören yaklaşımına hem de kendine bakışına bir eleştiri getirilmektedir. 
Mickey ve Mallory hakkında sadece ABD'de değil, Tokyo, Londra, Paris gibi dünyanın çeşitli yerlerinden yapılan sokak röportajları ekrana yansır. Sokak röportajlarında Mallory ve Mickey hakkındaki görüşler: “Çok ateşliler.," “Mickey ve Mallory'i çok seviyorum. Çok havalılar. Çok süperler.," "Mason'dan beri toplu katliamda en iyi onlar. Daha bile sıkılar." şeklindedir. İkili, gençler arasında küresel bir medya fenomeni haline gelmiştir. Dergilere kapak olmaktadırlar. Zaten medyanın gücü de buradadır: ünlü etme!

Bazı gençlerin “Öldür beni Mickey!” yazılı T-Shirt'ler giydiği görülür. Burada şiddet ve ölüm kavramları gerçek bağlamlarından koparılıp, birer eğlence aracına indirgenmekte ve tüm bunlar TV aracılığıyla görünür olduğundan medyaya karşı eleştirel bir yaklaşım sergilenmektedir. Yine sokakta “Öldür beni Mickey!” pankartı taşıyan kızın gösterilmesini, şiddet eğilimli kişilerin sapkınca idolleştirilmesine dönük anlamlı bir eleştiri olarak okumak mümkündür.

Mickey ve Mallory'in oteldeki yatak odalarında duvarlara yerleştirilmiş sanal dev ekranlarda ekolojik ve tarihsel bağlamda saldırganlık-şiddet görüntüleri akar: Stalin, toplu katliamlar, savaş, Hitler, soykırım, ölüm, kan, hayvanların birbirini yemesi... Gerek insanlık tarihinin trajedileri gerekse doğada hayvan türlerinin birbirlerine uyguladıkları vahşi beslenme pratikleri gerçek bağlamlarından koparılarak ve ardı ardına dizilerek bir film gibi sunulur. Zira Mickey, bu görüntülerin gerçekliklerini yadsıyarak: "Neden böyle saçma sapan filmler yaparlar. Hollywood artık öpüşmeye inanmiyor mu?" der. Şiddeti eğlence amaçlı edimleyen Mickey, ironik şekilde şiddetin gerçekliğini yadsımakla kalmaz aynı zamanda Hollywood ile alay da eder. Burada, gerçek ile sanal arasındaki ayrımın belirsizleşmesi hatta ortadan kalkması yine medya eleştirisi bağlamında çok güzel sorgulanmaktadır.

Yılan, filmde en yoğun olarak kullanılan hayvan figürüdür. Mickey, Mallory'e yılanlı yüzügünü asla çıkarmaması gerektiğini söyleyerek ve yılanbaşını kastederek "Yaptığımız tüm güzel şeylerin başı bunlar." der. Mickey’e göre yılanın temsil ettiği değerler, Mickey'in kendi dünyasına ait olduğunu düşündüğü değerlerdir.

\section{Kesit-4: Medyatik Şiddetin Eleştirisi}

Mickey ve Mallory yarı kurak bir bölgeye giderler. Ekranda ölü hayvan ve tıslayan çıngıraklı yılan görüntüleri belirir.

Mickey ve Mallory, bir Kızıldereli kulübesine girerler. Odadaki yaşlı Kızıldereli'nin yanında torunu ve bir yılan vardır. Mickey ve Mallory, içerideki yılandan korkarlar.

Kulübede, Mallory'in üzerinde "demon" (șeytan) ve ardından da Mickey ve Mallory'in üzerlerinde "too much TV" (çok fazla TV) 1şıklı yazılar belirir. Burada filmdeki en keskin ve açı medya eleştirisi yapılmıştır. Mickey ve Mallory'in kötü karakterleri onları şeytanlaştırmakta ve bunun da sorumluluğu TV'ye yüklenmektedir. Ancak burada “şeytan"ın medya aracılığıyla mı doğduğu yoksa medya aracılığıyla mı görünür hale geldiği hususu açık olmadığından, eleștiri yoruma bağlı hale gelmektedir.

Ortam çok kasvetlidir. Mickey "Sanki alacakaranlık kuşağındayız." der. Ardından Mallory'e "Sheytanları hissediyor musun?" diye sorar. Mallory "Galiba şeytanlar biziz." diye karşıllk verir. Mallory'in üzerinde bu kez "She crazy" (O çılgın) yazısı belirir. Kızıldereli'nin torunu, dedesine "Bu kız deli mi?" diye sorduğunda Kizıldereli "Kötü bir hastalı̆̆ı var. Hayaletlerin dünyasında kaybolmuș.” yanıtını verir. Kızıldereli 
şiddetin kaynağı olarak kötülüğü bilinçli bir tercih olmaktan ziyade bir hastalık olarak görmektedir. Bu nedenle Kızıldereli Mallory'i ahlaki olarak yargllamaz. "Hayaletlerin dünyasında kaybolmuş." ifadesiyle onu gerçeklikten kopmuş, psikiyatrik bir vaka olarak tanımlar. Çocuğun "Yardım edebilir misin büyükbaba?" sorusuna da "Belki de yardım istemiyorlardır.” yanıtını veren Kızıldereli, kötülük istenci konusunu oldukça göreceli bir hale getirir.

Büyükbaba, yılanı eline alır ve şu hikâyeyi anlatır: "Kadının biri ormanda bir yılanla karşılaşır. Yılan donmuştur ve ölmek üzeredir. Onu evine götürür ve iyileştirir. Ancak yılan, kadını ısırır. Kadın ölmek üzereyken yılana bunu neden yaptığını sorar. Yılan da kadına yılan olduğumu biliyordun karşılığını verir." Bir yılan besicisi olarak Kızıldereli kötülüğe karşı hem determinist bir yaklaşım sergiler hem de kötülügün insana özgü bir nitelik olarak değișebilen niteliğinin farkındadır. Bu durum, Kızıldereli'nin yılanı elinden birakarak "Git ve yılan ol.", torununa ise "Git ve adam ol." demesinde net olarak görülür. Kızıldereli, kötülüğün insanların bilinç ve tercihleriyle ilgisini çok yönlü sorgulatır. Modern dünyadan ve onun taşıyıcısı olan TV'den uzak bir yaşam süren Kızıldereli filmde modern-öncesi mistik bir bilgeliği temsil eder.

Mickey, Kızıldereli'yi öldürür ve Mallory'e istemeden olduğunu söyler. Bu söylem kötülüğün olası istem-dışı doğasına bir gönderme anlamına da gelmektedir. Kızıldereli ölmek üzereyken "20 yıl önce rüyamda şeytanı gördüm. Sizi bekliyordum." der. Kızıldereli’nin kastettiği “şeytan” aslında TV'dir. Kızıldereli kaderci bir yaklaşımla Mickey ve Mallory'in kötücül gerçekliğini kabul etmiştir.

Kızıldereli'nin torunu Mickey ve Mallory'e; "Sizi şeytanlar. Ne yaptınız!' diye bağırır. Mickey, kendilerine iyilik yapan bir kişiyi öldürerek kötüler hiyerarşisinde üst sıraları zorlamaktadır. Mickey'in bindiği arabanın aynasında korkunç bir yüz belirir. Bu yüz Mickey'in içindeki kötülüğün bir yansımasıdır. Kimseden korkmayan Mickey, kendinden korkmaya başlamıştır.

Mallory, Mickey’e Kızıldereli'yi öldürdügü için sitemde bulunur. Burada Mallory ilk defa pişmanlık duygusu göstermektedir. Mickey ve Mallory etrafta çok sayıda yılanın saldırısına uğrar. Kızıldereli'nin lanetine uğramış gibidirler. Sanki görünmez bir el artık onları cezalandırmaktadır.

Mickey ve Mallory, yılan panzehiri bulmak için bir markete girerler. Market görevlisi TV'de izlediği Mallory ve Mickey'i tanır ve polis çağırır. Mickey ve Mallory, market görevlisini de öldürürler ancak çıkışta bir polis ekibi onları beklemektedir. Medya ordusu eşliğinde abartılı çatışma ve ardından linç görüntüleri eşliğinde Mickey ve Mallory sonunda yakalanır.

\section{Kesit-5: Şiddet Kendini Savunuyor}

Mickey ve Mallory tutuldukları hapishanede diğer mahkumların gözünde birer fenomen haline gelmiştir. Polislerden biri, ikili için "Bu iki kişi sistemin rezilliğinin canlı birer örneği." der.

Gale, bir psikiyatr ile Mickey ve Mallory hakkında röportaj yapar ve doktora bunların deli olup olmadığını sorar. Doktor: "Deli değiller, psikozlular. Bunlar doğru ve yanlış arasındaki farkı biliyorlar. Sadece umurlarında değil." karşılığını verir. Doktorun yanıtı şiddetin bir akıl hastalığından kaynaklanan bilinçsiz bir edim mi ya da bilinçli bir tercihin ürünü mü olduğu hususundaki tartışmaya sşık tutacak niteliktedir. 
Psikiyatrın yanıtı, şiddetin doğası üzerine yazılar yazan J.J. Rousseau'nun şiddetin akıllı bireylerin değil duyarlı bireylerin yetiștirilmesi ile önlenebileceği hususundaki görüşlerini de destekler niteliktedir. İkili deli değil, duyarlılık geliştirememiş ilkel karakterlerdir. Şiddeti yaratan gerçekte medya değildir, ancak şiddetin görünür hale gelerek, kanıksanmasına bazen de meşrulaştırılmasına hizmet eder. Çok boyutlu ve karmaşık bir konu olan şiddette tüm sorumluluğu medyaya yüklemek indirgemeci bir yaklaşım olmakla birlikte, medyanın rolü de göz ardı edilemez.

Gale, Mickey'e röportaj teklif eder ve Mickey bu teklifi kabul eder. Mickey, bu kez konuşan bir kahraman olacağını ve yeni bir kariyer edineceğini söyler.

Gale'nin Mickey ile röportajında ilk olarak ona "Öldürmeye ilk ne zaman başladın?" sorusunu yöneltir. Mickey, öldürmeye doğumda başladığını, kanında bulunan şiddetin içinden geldiğini söyleyerek "Babamda da vardı. Onun babasında da. Bu benim kaderim." der. Bunun üzerine Gale'nin "Kimse kötü doğmaz. Öğrenirsin. Nasıl oluyor da masum birini öldürebiliyorsun?" sorusuna Mickey işlediği cinayetleri doğallaştırma çabasına girerek insan dahil tüm türlerin birbirini öldürdüğünü insanın ise tüm türleri öldürdügünü söyleyerek ölmeyi hak eden pek çok insan tanıdığını belirtir. Bunun üzerine Gale'nin “Neden ölmeyi hak ediyorlar?” sorusuna Mickey herkesin geçmişinde günahları bulunduğunu ve sefil hayat süren insanların bundan kurtulmaları gerektiğinde kaderin elçisi olarak devreye girdiğini söyler. Gale'nin "Herkes bir seri katil tarafindan öldürülmeyi hak mı ediyor?" sorusuna ise Mickey "Kurt neden kurt olduğunu bilmez. Tanrı öyle yaratmıștır." diyerek eylemlerini determinist bir anlayışla meşrulaştırmaya girişir. Gale'nin "Seninle tanıştığı için elli iki kişi öldü. Bunu gerçekten nasıl yapabildin?" sorusuna ise Mickey son derece aşağılayıcı bir tavırla kendisini aynı türden bile görmediğini belirttiği Gale'nin maymun bile olmadığını, korku alıp-satan bir medya mensubu olarak saf olan cinayeti kirlettiğini söyler. Bunun üzerine sinirlenen Gale, Mickey'e "Öldürmenin saflıkla ne ilgisi var? Yalan söyleme." diyerek çıkışır. Mickey de "Bunun için silahı eline almanız gerek. O zaman anlarsın. İlk seferinde bana da olmuştu. İlk gerçek çağrıyı işte o zaman anladım." karşılığını verir. Gale'nin "Neydi o?” sorusuna ise Mickey “Ben katil olarak doğmuşum." yanıtını verir. Çekim bitiminde Gale, memnuniyetinin bir ifadesi olarak "harika" der. Röportaj esnasında bir ara Mickey'in yüzünün görüntü teknikleriyle bulanıklaştırılarak, rahatsız edici hale getirildiği görülür. Burada şiddetin; tahrip edici ve bozucu yüzü temsil edilir.

Röportajda bazı önemli noktalar göze çarpmaktadır. Mickey'in şiddeti doğallaştırdığl, kaderci yaklaşımına karşın Gale'nin eğitimle ilgili saptaması önemlidir. Yine Mickey işlediği cinayetleri, ormanda hayvanların birbirini yemesi ile karşılaştırarak temelde ikisinin aynı şey olduğunu söylemektedir. Hâlbuki hayvanların birbirini yemesi şiddet değil saldırganlıktır ve türün devamını sağlamaya yönelik doğal bir süreçtir. Şiddet ise tamamen insan özgü ve bilinçli bir edimdir. Mickey kendisini popüler yapması için kullanmaya çalıştığı medya mensuplarını "Maymun bile değilsiniz." diyerek aşağılamakta ve şiddeti kirletenin medya olduğunu söyleyerek medyanın korku alıp korku sattığını ifade etmektedir. Mickey'in röportajdaki tek doğru sözü, medyanın korku alıp sattığıdır. Çünkü bu, medya için her koşulda reyting demektir.

\section{Kesit-6: Şiddetin Zaferi}

Röportajdan sonra hapishanede ayaklanma başlar. Mickey firsatını bulup etrafındaki polisleri öldürür. Gale, Mickey'in yanında olan biteni kanalına canlı olarak 
aktarmaktadır. Mickey, Gale'nin tanıklığında Mallory'i kurtarır ve ikili kucaklaşır. Gale, Mickey ve Mallory'in tarafını tutan konuşmalar yapmaktadır. Mallory, Scagnetti'yi öldürür.

Mickey ve Mallory; Gale ve diğer bir kişiyi esir alarak kaçarlar. Kaçtıkları yerde Gale, Mickey ve Mallory ile röportaj yapar. Mickey ve Mallory, Gale'i de öldürmek isterler. Gale, onlarla beraber kaçtıklarını, aralarında bağ oluştuğunu sandığını söyler. Bunun üzerine Mickey, Gale'i kendinden başka kimseyi düşünmemekle suçlayarak, reyting için yaptığını söyler. Gale ise Mickey'e Kızıldereli olayını hatırlatıp "Hani öldürmeyecektiniz.” der. Bunun üzerine Mickey, Gale’ye öldürmezlerse kimseden farklarının kalmayacağını ve öldürecekleri son kişinin kendisi olacağını söyleyerek, bu ölümün bir bildirim sonucu olacağını söyler. Gale’nin “Öldürdüğünüz gün bizim elimize düştünüz. Halkın. Medyanın. Biz evlendik, değil mi? Hikâyenizi anlatmakiçin să̆ bırakın beni." demesi üzerine Mickey son olarak "Bırakıyoruz. Kameranı." karşılığını verir ve ardından Mickey ve Mallory, Gale’yi de öldürürler. Gale'nin kamerası bu acı sonu kaydettiğinde, $o$ anda bir kurban haline gelen Gale'nin şahsında somutlaşan vicdanın, teknolojik determinizme yenilişi de ölümsüzleşmiş olur.

Son kesitten anladığımız üzere medya, kendi yarattığı gerçekliğe teslim olmuş, şiddet mahkûm olmamış, tersine galip gelmiştir. Medya reyting için şiddeti kullanıyorsa, şiddette varlığı için medyayı kullanmakta ve sonunda varoluşsal gücünü medyanın üzerine koyarak, medyanın gücünü aşmaktadır. Hikâyenin sonunda Mickey ve Mallory'in hikâyelerini anlatmak için kimseye ihtiyaçları kalmadığını sadece kameranın yeterli olduğunu söylemeleri de aslında Marshall McLuhan'ın vurguladığı teknolojik determinizme gönderme yapmaktadır.

Kayıplara karışan Mickey ve Mallory'in daha sonraki yıllarda çocuklarıyla birlikte karavanlarında gezerek hayatlarına devam ettikleri filmin sonunda anlaşılmaktadır.

\section{Dizisel Çözümleme/Karşıtlıklar}

Anlatı örgüsü içerisinde anlam üretimi, geliştirilen karşıtlıklar üzerine kurulmaktadır. Natural Born Killers filminde anlam üretiminin çıkış noktası, medyanın toplumsal şiddeti popüler hale getirme rolü üzerine eleştirel bir bakış açısı geliştirmektir. Bunun için de filmde çeşitli karşıtlıklar oluşturulmaktadır.

Filmde gördüğümüz ilk zıtlık, ahlak felsefesinin de en temel kategorisini oluşturan iyi ile kötü arasındaki zıtlıktır. İyi ile kötü arasındaki zıtlık burada şiddet temeli üzerinden sorgulanmaktadır. Mallory ve Mallory'in kurbanlarına uyguladıkları şiddet fiziksel (doğrudan) şiddetin en uç örneğini temsil etmekle birlikte aslında kategori dışı dahi sayılabilir. Çünkü onlar için kendileri dışındaki herkes "bir şekilde" ölmeyi hak etmektedir. Mallory ve Mickey; "iyi” ve "kötü" kavramlarını yapı bozumuna uğratıp, ters yüz eder, hatta anlamsızlaştırır. Onların bakış açılarına göre işledikleri nedensiz cinayetler kötü bir şey değildir. Ya da kötü olduğu için iyidir. Mallory ve Mickey'in bu konuda tutarlı bir duruş sergilemez. Mallory ve Mallory'in şahsında somut hale gelen kötülüğün karşında bunları durdurmaya çalışan sistem (hukuk, devlet) ise yalnızca kötülüğü engelleyici anlamda iyidirler. Medya ise filmde iyinin yanında değildir çünkü iyi olan değil, kötü olan reyting getirmektedir. Medya kötü olmaktan ziyade kötünün yanındadır. Filmdeki medya eleştirisi genel olarak bu doğrultuda işlenmektedir. 
İlk zıtlı̆ga paralel olarak filmdeki ikinci zıtlık, sevgi ile nefret arasındaki zıtlıktır. Filmde en karmaşık şekilde işlenen zitlığın bu olduğu söylenebilir. Toplumsal olan her şeyden nefret eden Mallory ve Mickey'in sevgisi yalnızca birbirleri için geçerlidir. Kendileri dışında olan her şeyden nefret etmektedirler. Mallory ve Mickey bir benzetmeyle nefretin diși ve erkek versiyonları olarak kendilerini adeta tek ve ayrılmaz olarak görmektedir. Filmde cani olarak işlenen Mallory ve Mickey'in birbirlerine aşık olması, iyilik ve kötülük ile aşk kavramları arasındaki çizgilerin bulanıklaşmasına yol açar. Reyting kaygısıyla kötülerin aşkını parlatıp sürekli ekrana taşıyan medya ise nefret dolu iki aşığın hikâyesinden yararlanmak isteyen rolde işlenerek, eleştirilmektedir.

Filmdeki üçüncü zıtlık, Mallory'ingeçmişinde babası tarafından cinsel tacize uğraması vakasında görüldüğü üzere zalimlik ve mağduriyet üzerinedir. Şiddet eğilimli sapkın bir babanın, öz kızını taciz etmesinin filmde sitcom benzeri bir seyirlik eğlence havası içinde gösterilmesiyle, medya kişisel trajedileri ele alış tarzıyla ilgili açıkça eleştirilmektedir. Geçmişinde mağdur olan Mallory'in Mickey ile tanışmasıyla bir caniye dönüşmesi ve nedensiz yere pek çok kişiyi öldürmesinde de görüldüğü üzere filmde mağdur ve zalim rolleri zaman ve bağlama göre değişmektedir.

Filmdeki dördüncü zıtlık, Mallory ve Mickey'in şahsında geçmiş ile gelecek arasında kurulan zıtlıktır. Kötülük yaparak büyüdüklerine inanan Mallory ve Mickey, geçmiş hayatlarına dair ne varsa kurtulmak istemekte, geçmişlerinden intikam alma hevesiyle kendi geleceklerini inşa etme rolüne girişmektedir. Filmde bu durum, ikilinin cinayetlerinden sonra kendilerine yeni kıyafet almaları gerektiğini söyleyerek eski kıyafetlerini ve eşyalarını köprüden aşağı atarak kutlamaları ile gösterilmiştir. Mickey ve Mallory'in eski eşyaları onların geçmiş yaşantılarından tamamen koparak ondan kurtulmak istemelerini sembolize etmekte, yeni alacakları klyafetler ise üzerine giymek istedikleri birer eşyadan ziyade ulaşmak istedikleri yeni konumlarını temsil etmektedir. Ancak inșa etmek istedikleri geleceğin ne olduğuna dair Mickey ve Mallory için belirgin bir tablo ortaya konmaz. Nihilist bir kötücülüğü temsil eden Mickey ve Mallory'in dünyalarında kötülük bir karadelik gibi her șeyi yok etmekte ve hayata dair hiçbir sevgi ve umut ışığına yer bırakmamaktadır. Mickey ve Mallory karakterleri aslında toplumbilimci Eric Fromm'un üzerinde sıklıkla durduğu ve birbiriyle çatışma halinde gördüğü yaşam ve ölüm sevgisi ayrımında ölüm sevgisinin katışıksız temsilcileridir.

Filmdeki beşinci zıtlık, toplumsal olan ile toplum dışı olan arasındaki zıtlıktır. Mickey ve Mallory ileri düzey davranış bozuklukları ve şiddet eğilimleriyle toplum dışı insan profilinin uç örneğidir. İnsanları nedensizce öldüren Mickey ve Mallory, toplumdaki herkesi potansiyel birer kurban haline getirmekle, kamu düzenini tehdit edici hale gelerek mahkeme önüne çıkmak üzere polisleri peşinden sürükler. Filmde; Mickey'in, Mallory'e evlenme teklif etmesi ve Mallory'in kabul etmesi üzerine "Nerede evlenelim?" sorusuna Mickey'in "Bizim kilisemiz burası." diyerek köprünün üzerindeki açıklık alanı göstermesinden ve Mickey'in Mallory’e yüzüğü taktığında "Kendi dünyamın Tanrısı'nın bana verdiği yetkiye dayanarak bizi karı-koca ilan ediyorum." demesinden ikilinin toplum dışı konumlarının farkında oldukları anlaşılır. Mickey ve Mallory'in toplum dışı konumlarını yücelterek, ünlü olma heveslerine hizmet eden medya, yine eleştirel bir bakış açısıyla yargılanmaktadır. 
Filmdeki altıncı zıtlık, şiddetin kaynağı üzerinedir. Bu zıtlık, Mickey ve Mallory'in kulübede Kızıldereli'yi öldürmeleri ile sonuçlanan sekansta sorgulanmıştır. Kızıldereli, kulübeye gelen Mickey ve Mallory'i ahlaki olarak yargılamaktan ziyade hasta olarak görür. "Hayaletlerin dünyasında kaybolmuşlar." ifadesiyle Kızıldereli onların gerçeklikten kopuk hasta bireyler olarak yaptıkları kötülüklerin bilincinde olmadıklarını düşünmektedir. Buna karşın Gale'nin röportajında psikiyatr; Mickey ve Mallory'in deli olmadığını ancak psikozlu birer hasta olarak yaptıkları eylemleri bilinçli olarak yaptıklarını sadece umurlarında olmadıklarını belirterek onları ahlaki olarak yargılar. Böylece şiddetin kaynağı ile ilgili temel zıtlık görünür hale gelir: Şiddet, doğru ve yanlışın farkında olarak bir tercihin sonucu mu yoksa bu farkın işlemediği bilinçsiz bir edim midir? Şiddet, bir akıl hastalığının sonucu ise ahlaki olarak yargılanabilir mi? Daha da önemlisi sınıflamanın neye göre yapılacağı, hangi olguda neyin geçerli olduğunun sınırının nerede bașlayıp, sona ereceği ve hükmün kim tarafından hangi kritere göre verileceğidir. Tartışmalı olan konuda film net bir mesaj vermemekle birlikte medyanın şiddeti popülerize etme işlevine ilişkin eleștirel yaklaşım net olarak görülür. Kulübede Mickey ve Mallory'in üzerinde beliren "too much TV" (çok fazla TV) yazısı ile medya, șiddetin ortaya çıkışı ve yaygınlaşmasındaki rolüne ilişkin açıkça yargılanmaktadır.

Filmdeki yedinci zıtlık, sıradan ile medyatik ayrımı üzerinedir. Buradaki zıtlık medyanın ünlü etme işlevi ve bunun şiddet temelinden inşasının sonuçları bağlamında eleștirel olarak ele alınmaktadır. Daha önce sıradan karakterler iken bunu aşma hevesiyle cinayetler işleyen Mickey ve Mallory; medyanın ilgi odağı haline gelmeleri ile artık kendi gerçekliklerini inşa eden değil, bunu medya aracılığıyla herkese dayatan birer aktör konumundadır. Medyanın reyting amacıyla insan hayatını ilgilendiren en ciddi konuları dahi seyirlik bir eğlence haline getirmesi filmdeki en temel eleştirilerden biridir. Medya sıradan olanı meşhur edemeyeceği gibi sıra dișı olanlar her zaman iyiler olmaz. Medya; kötülüğün getirdiği yüksek reytingi kullanan taraf olduğu gibi; kötülük tarafından kullanılan da olabilmektedir. Yine medyanın meşhur ettiği Mickey ve Mallory'in, sıradan insanların gözünde saplantılı bir şekilde kahraman hale gelmeleri ve medyanın bu konuyu ele alışı da konunun bir başka boyutunu oluşturur. Filmdeki sokak röportajlarında Mickey ve Mallory'e hayranlık duyan gençlerin karikatürize edilmiş ifadeleri, şiddete yönelik ilgiyi, hayatın sıradanlığının eğlence aracı olarak şiddetle aşılmaya çalışılmasına bağlayan ve bu konudaki medyanın rolünü de sorgulayan kapsamlı bir eleștiridir. Sokak röportajlarında gençler, Mickey ve Mallory'i bir bilgisayar oyunundaki insan öldüren karakterler gibi heyecan verici bulmakta ve burada gerçek ile sanal arasındaki ayrım da eleştirel bir yaklaşımla kasti olarak bulanıklaştırılmaktadır.

Filmdeki sekizinci zıtlık, doğuştan gelen ile öğrenilen arasındaki zıtlıktır. Bu zıtlıkta şiddet eğiliminin doğuştan mı geldiği ya da sonradan öğrenilen bir davranış mı olduğu yine medyaya karşı eleştirel bir bakış açısıyla sorgulanır. Yakalandıktan sonra Gale ile röportaj yapan Mickey; kendisinin doğuştan şiddet eğilimli biri olduğunu, bu özelliğinin babasında da büyük babasında da var olduğunu söylemekte ve şiddet eğilimini doğallaştırma çabası içine girmektedir. Yine Mickey; şiddet dolu bir ortamda büyüdügünü söyleyerek şiddetin çevreyle öğrenilip benimsenen özelliğine vurgu yapmaktan da geri kalmaz. Zira Mallory'in geçmişinde babasından cinsel taciz görmesi onun şiddet eğilimini güçlü şekilde etkilemiş görünmektedir. Gale'nin Mickey'e "Kimse katil doğmaz. Öğrenirsin." demesi şiddetin eğitimle terbiye 
edilebileceğine yani öğrenme ile kader olarak görülen şeyin değiştirilebileceğine dair anlamlı bir ifadedir. Bu bir anlamda kadercilik ile değiştirilebilirlik arasındaki zitlıktır. İki argümanın da işlendiği filmde bu konuda kesin bir şey söylenmemekle birlikte; olması gerekenden çok olası alternatifler ön plandadır. Olması gerekenden çok olanı göstermesi bakımından şiddete hizmet eden medya, kimi zaman onu yücelterek, kimi zaman da seyirlik bir eğlenceye dönüştürerek izleyiciye sunduğu gerekçesiyle eleştirilmektedir.

\section{Sonuç}

Günümüzde şiddetin toplumsal boyutta artış içinde olduğu ve teknolojik gelişmelerle daha da görünür hale geldiği göz önüne alındığında şiddet temalarıyla yüklü medyanın çocuklar başta olmak üzere alıcllar üzerindeki biyo-nörolojik ve sosyolojik etkilerini anlamanın önemi de yadsınamaz bir gerçeklik olarak karşımıza çıkmaktadır.

Oliver Stone, doğuştan katillerin her zaman var olabileceği bir dünyada televizyonun onları reyting kaygılarıyla birer pop yıldızı gibi sunmasının, asıl suç olduğunu mu söylüyor? (Körte, 2006, 94). Natural Born Killers filminde şiddet bağlamında yapılan medya felsefesinde; televizyon hedef tahtasına oturtulmakta, TV toplumuna ciddi eleştiriler yöneltilmektedir. Üstelik bu eleștirilerden yalnızca reality-showlar değil, çizgi filmlerden reklamlara kadar televizyonun tüm enstrümanları nasibini almaktadır.

Tüketim kültürünün toplumdaki tüm değerleri sermayenin çıkarları doğrultusunda emip tükettiği ve duyarsız insan kitleleri yarattığı günümüz dünyasında, özellikle sosyal medyanın ortaya çıkıp gelişmesiyle sıradan insanın yine sıradan insanlara karşı ünlü olma hevesi artarak devam etmektedir. Zararsız beklenti ve amaçlar bağlamında bu elbette masum görünebilir. Ancak ünlü olma hevesi zararlı insanların yegâne amacı haline geldiğinde medyanın rolü burada kilit rol oynamaktadır. Televizyonsuz ve televizyon toplumu olmaksızın Mickey ve Mallory gibi insanlar var olabilir mi? İște TV-toplumunun, medyatik toplumun işlevi de burada saklıdır. Filmde bazı Mickey hayranlarının, “Öldür beni Mickey!'”yazılı T-Shirt'ler giydiği görülür. Bu, zekâ gelişiminden bağımsız bir husus olarak, empati yoksunu ve yanlış yönlendirilmeye müsait kişilerin insanlığa zararlı figürleri nasıl sapkın bir yaklaşımla idolleştirdiğine yönelik anlamlı bir dokundurmadır. Filmde bu görüntüler hiciv niteliğinde ele alınsa da tarihin insanoğluna öğrettiği en büyük derslerden biri milyonlarca insanın yine milyonları öldüren liderlerin peșinden körü körüne gittiği değil midir? Bu liderler de medyayı kötü emelleri için birer propaganda amacıyla kullanmadılar mı? Filmde tarihe dönük bu göndermeler (Hitler, Stalin, savaş görüntüleri vs.) zaman zaman gayet yerinde bir şekilde yapılmıștır.

Filmde, şiddetin nedenleri üzerinde kesin yargılar bulunmazken; cinayetler anlık tepkiler ve nedensiz bahanelere dayalı öfke patlamalarının sonucu olarak sunulur. Her türlü şiddeti sergileyen bir araç olarak televizyonun şiddeti görsel bir şova dönüştürerek çeşitli formatlarda kitlelere aşılayan bir günah kutusu olarak gösterildiği filmde; kitlelerin idrak kabiliyetlerinin önemi üzerinde durulmaz. TV toplumu, idrak yeteneği zayıf, eğitimsiz ve manipüle edilmeye açık bir kitle olarak, TV'ye esir olmuş bir toplum olarak sunulur. 
Oliver Stone, Hollywood sinemasının klasik anlatım ilkelerine itibar etmezken, bu sinemanın gerçeklik yanılsamasının da altını çizer. Stone; belgesel çekimler, video çekimleri, Süper-8 kayıtları, buzlu cama yansıtma teknikleri, görüntülerin renkleriyle oynamalar, sitcom'lar (durum komedisi), kitsch melodramlardan parçalar, video klipler, çizgi film parçaları, reklam spotları gibi hileleri birbirleriyle hem karıştırarak hem de düğümleyerek karşımıza ilk bakışta kafa karıștırıcı bir estetik düzlem çıkarır. $\mathrm{Bu}$, gerçekliğin estetik düzlemde kurulması ya da ortadan kaldırılması düzlemidir. Gerçeklik kendi imgelerine teslim olmuş; görüntü gerçekliği, inşassının aracına indirgemiștir. Seyirci bu filmi izlerken artık sinema değil televizyon seyretmektedir. Bir kanaldan ötekine zap yapan seyircinin yerine, gösteri kendi zap'ını yapar. Ancak bu geçişler bir iç zorunluluğun, anlatılan öykünün araçlarıyla yapılan dolaşmanın sonucu değildir. Yönetmen, uzaktan komuta araciyla zaplamakta, kimi kareler gözümüzün önünden algıya imkân bırakmayacak kadar hızlı geçmektedir. Neyi belgelemektedir bu "sahte belgesel gösteri", gösteri olduğunun ötesinde? Gerçeklikle televizyonun gerçekliği arasında ayrım yapamayanlar seyirciler mi, katil sevgililer midir? (Körte, 2006, 93-94).

Hiciv özelliği, filmde hem bir çok anlatım tekniğinin kullanılmasına fırsat vermiş hem de abartmalara zemin hazırlamıștır. İki katilin yanı sıra, polis ve televizyon yorumcusu olan karakterler inandırıcılık ve derinlikten uzaktır. Olaylara ani tepki veren, duygusal taşkınlıklar sergileyen ve kontrolsüz tipler olan karakterlerin yer yer karikatürize edildiği göze çarpmaktadır.

Filmde gördüğümüz tek bir sahne bile bizde gerçek olduğu izlenimini yaratmaz. Gördügümüz her şey bize anında televizyondan tanıdığımız görüntüleri çağrıștırır. Örneğin, geri dönüşle Mallory'in babası tarafından cinsel tacize uğrayıșını ve birlikte annesi ile babasını öldürdükleri Mickey ile ilk karşılaşmasını gösterirken, bu sekansı "I love Mallory" başlığı altında bir durum komedisi tekniğiyle sunar; yetmezmiş gibi konserve gülmeleri de ihmal etmez. İki garson kızın ve üç müşterinin öldürülüşünü de heavy-metal grubunun video klibi olarak sunar. Birkaç öldürme bölümü ağır çekimle verilmiştir (Körte, 2006, 96-97).

Film, toplumu bir TV-toplumuna indirgeyip şiddeti iki sadist figürle ilişkilendirmekle, şiddetin (suçun) sorumluluğunu da televizyona, reyting kayglarına ve TV toplumuna yüklemektedir. Filmde şiddetin temelinde yatan nedenler hakkında bir hüküm verilmemekte, şiddet medya eleştirisi bağlamında ele alınıp, anlatı üslup üzerinden inşa edilmektedir. Yönetmen seyirciye yalnızca buzdağının üstünü göstermekte, birey-toplum diyalektiğini kavrama bakımından kayda değer bir analiz yapmamaktadır. Mesajları basit, anlaşılır ama bağlamlarından koparılmış ve ucu açıktır.

Medyanın reyting için şiddeti kullanmasına karşı, şiddetin medyayı kullanması denkleminde kazanan tarafın şiddet olduğu tezi üzerine inşa edilen filmin sonunda şiddetin galip gelmesi, adil bir son bekleyen izleyici için moral bozucu görünmekle birlikte günümüzde şiddetin her yerde ve önlenemez olduğu gerçeği ile uyum içindedir. 


\section{Kaynakça}

Archer, D. ve Gartner R. (2007). Barış Dönemi Kayıpları: Savaşa Katılmayanların Şiddet İçeren Davranışlarında Savaşın Etkisi. Cotigo, 6-7, 237-252.

Büyük Larousse Sözlük ve Ansiklopedisi (1986). c. 21, s. 11073. İstanbul: Milliyet Yayınları.

Çakır, S. (2008). Medya ve Şiddet. Doğu Batı, 43, 161-180.

Ergil, D. (2001). Şiddetin Kültürel Kökenleri. Bilim ve Teknik, 399, 40-41.

Erten, Y. ve Ardalı C. (2007). Saldırganlık Şiddet ve Terörün Psiko-Sosyal Yapıları. Cotigo, 6-7, 143-163.

Fiske, J. (2003). İletişim Çalışmalarına Giriş. (S. İrvan, Çev.). Ankara: Bilim ve Sanat Yayınlarl.

Göka, E. (1989). İnsanda Şiddet Davranışının Nedenleri. Bilim ve Teknik, 264, 25-26.

Gümüşoğlu, F. (2006). Bilgisayar Oyunlarında Şiddet, Çocuklar ve Gençler, F. Gümüşoğlu (Ed.). Terör, Şiddet ve Toplum (s.97-113). İstanbul: Bağlam Yayınları.

IMDB. Natural Born Killers. Erişim Tarihi: 05.02.2018. https://www.imdb.com/title/ tt0110632/

Kıroğlu, G. (2006). Şiddet, Terör ve Toplum. F. Gümüşoğlu (Ed.). Terör, Şiddet ve Toplum (s.19-25). İstanbul: Bağlam Yayınları.

Kocabaşoğlu, N., Savrun, M. ve Konuk, N. (2000), Sosyo-Kültürel Açıdan Şiddet. (Ed: İ. Balcıŏlu). Biyolojik, Sosyolojik, Psikolojik Açıdan Şiddet (s.27-31). İstanbul: Yüce Yayıncılık.

Körte, P. (2006). Şiddetin Mitolojisi. (V. Ataman, Der.). İstanbul: Don Kişot Güncel Yayınları.

Oktay, M. (1996). İletişimciler İçin Davranış Bilimlerine Giriş. İstanbul: Der Yayınları.

Oktik, N. (2008). Bireysel Bir Şiddet Olarak İntiharın Sosyolojik Açılımı. Doğu Batı, $43,199-218$.

Rifat, M. (2007). Homo Semioticus ve Genel Göstergebilim Sorunları. İstanbul: Yapı Kredi Yayınları.

Rifat, M. (2009). Göstergebilimin ABC'si. İstanbul: Say Yayınları.

Sanders, B. (2010). Öküzün A’sı. (2. bs.). (Ş.Tahir, Çev.). İstanbul: Ayrıntı Yayınları.

Turam, E. (2007). TV'deki Şiddetin Çocuklara Etkileri Üzerine Farklı Bir Bakış. Cotigo, 6-7, 391-406.

Ünsal, A. (2007). Genişletilmiş Bir Şiddet Tipolojisi, Cotigo, 6-7, 29-36.

Zülal, A. ve Yüce, S. (2001). Şiddet, Bilim ve Teknik, 399, 34-39. 